\title{
A new microsporidian species, Vairimorpha ocinarae n. sp., isolated from Ocinara lida Moore (Lepidoptera: Bombycidae) in Taiwan
}

\author{
Chih-Yuan Wang ${ }^{\mathrm{a}}$, Leellen F. Solter ${ }^{\mathrm{b}}$, Wei-Fong Huang ${ }^{\mathrm{a}}$, Yi-Chun Tsai ${ }^{\mathrm{a}}$, Chu-Fang Lo $^{\mathrm{c}, *}$, \\ Chung-Hsiung Wang ${ }^{\mathrm{a}, \mathrm{d}, \mathrm{e}, *}$ \\ ${ }^{a}$ Department of Entomology, National Taiwan University, Taipei 106, Taiwan \\ ${ }^{\mathrm{b}}$ Illinois Natural History Survey, University of Illinois, 1816 S. Oak St., Champaign, Illinois 61820, USA \\ ${ }^{\mathrm{c}}$ Institute of Zoology, National Taiwan University, Taipei 106, Taiwan \\ ${ }^{\mathrm{d}}$ Institute of Biotechnology, College of Bioresources and Agriculture, National Taiwan University, Taipei 106, Taiwan, ROC \\ ${ }^{\mathrm{e}}$ Institute of Zoology, College of Life Science, National Taiwan University, Taipei 106, Taiwan, ROC
}

\section{A R T I C L E I N F O}

\section{Article history:}

Received 24 May 2008

Accepted 12 November 2008

Available online 21 November 2008

\section{Keywords:}

Vairimorpha ocinarae n. sp.

Ocinara lida

Electron-dense granules

Ultrastructure

Phylogenetic analysis

\begin{abstract}
A B S T R A C T
A new microsporidium was isolated from Ocinara lida Moore (Lepidoptera: Bombycidae), a pest of Ficus microcarpa L. f. in Taiwan. The microsporidium produces systemic infections in $O$. lida larvae; the midgut epithelium, Malpighian tubules, and midgut muscle tissues were the target tissues for this isolate, and atrophied fat body tissues were found in heavily infected larvae. Two types of spores were observed, diplokaroytic spores with 11-13 coils of polar tube, and monokaryotic spores with 12 coils of the polar tube that developed within a sporophorous vesicle to form octospores. Electron-dense granules were abundant in the episporontal space of the sporophorous vesicles, and were similar to those of Vairimorpha invictae isolated from Solenopsis invicta, but different from granules or inclusions of other Vairimorpha species. Based on the phylogenetic analysis of the small subunit ribosomal DNA sequence, this isolate is unique within the Vairimorpha complex. Morphological and genetic characters showed this isolate to be a new species. It is placed in the genus Vairimorpha and is described as Vairimorpha ocinarae n. sp.
\end{abstract}

(ㄷ) 2008 Elsevier Inc. All rights reserved.

\section{Introduction}

Microsporidia are eukaryotic organisms that parasitize nearly all groups of animals (Canning and Lom, 1986). Lepidopteran larvae with microsporidiosis are commonly found in the field, and most of these microsporidia are classified into three genera, Endoreticulatus, Nosema, and Vairimorpha (Solter et al., 2000). Phylogenetic analysis of the small subunit ribosomal DNA (SSUrDNA) shows the genus Endoreticulatus to be a distinct clade (Wang et al., 2005), but the genera Nosema and Vairimorpha could not be separated into different clades using molecular characters (Ku et al., 2007; Tsai et al., 2003). The genus Nosema is defined as polyphyletic according to phylogenetic analyses, but Nosema and Vairimorpha are traditionally differentiated using morphological characteristics (Pilley, 1976). The life cycles of species in the genus Vairimorpha are more complex than those of Nosema spp. After the genus Vairimorpha was described by Pilley (1976), several microsporidian species were reassigned to this genus based on the pro-

\footnotetext{
* Corresponding authors. Fax: +886223638179 (C.-F. Lo);+886 227364329 (C.H. Wang).

E-mail addresses: gracelow@ntu.edu.tw (C.-F. Lo), wangch@ntu.edu.tw (C.-H. Wang).
}

duction of two types of spores, diplokaryotic single spores and monokaryotic octospores (Pilley, 1976; Vavra et al., 2006), the latter being the apomorphy for the genus Vairimorpha.

In 2006, fertilized females of Ocinara lida Moore (Lepidoptera: Bombycidae), a pest of Ficus microcarpa L. f., were collected near the campus of National Taiwan University and were reared in the laboratory. The microsporidian infections in the offspring were systemic and led to the collapse of the entire laboratory population. Observations of the infected tissues and pathogenesis showed this microsporidium to be different from the Endoreticulatus sp. that was previously recovered from the same host (Wang et al., 2005). In this paper, we describe this new isolate based on analysis of the SSUrDNA sequence and ultrastructural characteristics.

\section{Materials and methods}

\subsection{Host insect and microsporidian isolate}

Inseminated female $O$. lida moths were collected on the campus of National Taiwan University in Taipei, Taiwan. The moths were allowed to oviposit and the resulting larvae were reared on leaves 
of Ficus microcarpa L. f. in the laboratory at ambient room temperatures (approximately $29^{\circ} \mathrm{C}$ day, $12{ }^{\circ} \mathrm{C}$ night). Fourth- and fifth-instar larvae were dissected and tissues (midgut, fat body, and Malpighian tubules) were microscopically examined. Larvae with microsporidiosis were stored at $4{ }^{\circ} \mathrm{C}$.

\subsection{Spore purification and DNA extraction}

Infected host tissues were homogenized, filtered and centrifuged to purify mature microsporidian spores as described previously (Tsai et al., 2003; Wang et al., 2005). The purified spores were stored in the TE buffer (0.1 M Tris, 0.01 M EDTA, pH 9.0) at $4{ }^{\circ} \mathrm{C}$. The spore solution $\left(10^{8}\right.$ spores in $0.5 \mathrm{ml}$ TE buffer) and an equal volume of zirconia/silica beads $(0.1 \mathrm{~mm}$ diameter) were mixed in a $10 \times 75 \mathrm{~mm}$ glass tube and shaken at maximum speed on a vortex machine for 1 min (Undeen and Cockburn, 1989). The solution was treated with proteinase $\mathrm{K}$ and the DNA was extracted using a QIAamp DNA Mini Kit (Qiagen, Hilden, Germany) according to manufacturer's instructions. The DNA was eluted in $\mathrm{ddH}_{2} \mathrm{O}$ and stored in $-20^{\circ} \mathrm{C}$. DNA concentration and quality were measured on a GeneQuant pro spectrophotometer (Amersham, Bioscience).

\subsection{Amplification and sequencing of SSUrDNA}

The primer set (18f: 5'-CACCAGGTTGATTCTGCC-3'/1537r: 5'TTATGATCCTGCTAATGGTTC-3') was used to amplify SSUrDNA (Vossbrinck et al., 1987, 1993). The total volume of PCR is a 100$\mu \mathrm{l}$ reactive solution containing $100 \mathrm{ng}$ of DNA, $10 \mathrm{mM}$ Tris- $\mathrm{HCl}$, $\mathrm{pH} 9.0,50 \mathrm{mM} \mathrm{KCl}, 1.5 \mathrm{mM} \mathrm{MgCl}_{2}, 200 \mathrm{mM}$ of each dNTP, 100 pmol of each primer, and 2.5 U Hifi DNA polymerase (Yeastern Biotech). The amplification was performed in an AG-9600 Thermal Station (Biotronics Corporation) for 40 cycles, each with the following profile: $94{ }^{\circ} \mathrm{C}$ for $30 \mathrm{~s}, 50{ }^{\circ} \mathrm{C}$ for $30 \mathrm{~s}$, and $72{ }^{\circ} \mathrm{C}$ for $90 \mathrm{~s}$. A $10 \mu \mathrm{l}$ aliquot was run on a $1.0 \%$ agarose gel to visualize the PCR product. The DNA fragments were cloned into T\&A cloning vector (RBC, Bioscience) and both DNA strands were sequenced on an automated DNA sequencer (DNA sequencer 377, Applied Biosystems).

\subsection{Phylogenetic analysis}

The SSUrDNA sequences of the 0 . lida microsporidium were compared to Nosema and Vairimorpha sequences in GenBank (Table 1) for phylogenetic analysis. All sequences were aligned using the "Clustal X 1.18" program (Thompson et al., 1997) and then manually edited with the GeneDoc program (Nicholas et al., 1997). Encephalitozoon cuniculi was used as the outgroup. The analyzed

\section{Table 1}

NCBI GenBank accession numbers for Vairimorpha ocinarae n. sp. and Nosema and Vairimorpha species isolated from insects used to produce the SSUrDNA phylogenetic tree.

\begin{tabular}{lll}
\hline Microsporidia & Host & GenBank Accession No. \\
\hline Encephalitozoon cuniculi & Mammal & AJ005581 \\
Nosema bombycis & Bombyx mori & AY259631 \\
Nosema carpocapsae & Cydia pomonella & AF426104 \\
Nosema furnacalis & Ostrinia furnacalis & U26532 \\
Nosema oulemae & Oulema melanopus & U27359 \\
Nosema portugal & Lymantria dispar & AF033316 \\
Nosema spodopterae & Spodopterae litura & AF238239 \\
Nosema trichoplusiae & Trichoplusia ni & U09282 \\
Nosema tyriae & Tyria Jacobaeae & AJ012606 \\
Vairimorpha disparts & Lymantria dispar & DQ272237 \\
Vairimorpha imperfecta & Plutella xylostella & AJ131645 \\
Vairimorpha necatrix & Pseudaletia unipuncta & DQ996241 \\
Vairimorpha ocinarae & Ocinara lida & EU338534 \\
\hline
\end{tabular}

region (position 11-1223 of the new isolate) was chosen to calculate identities and analyze the phylogenetic relationship. The phylogenetic analyses based on the resultant alignments were constructed using the neighbor-joining, maximum parsimony, and maximum likelihood methods (PAUP 4.0b10; Swofford, 2003). The phylogenetic analysis was also performed using Bayesian inference (Rannala and Yang, 1996). The best-fitting model of DNA substitution was selected by the Akaike information criterion (AIC) using the "MrMTgui 1.0 program". The parameter was set as a GTR + I + G model. Bayesian analysis was performed using "MrBayes version 3.1.2" (Huelsenbeck and Ronquist, 2001). Analyses were initiated with random starting trees, then run for $1 \times 10^{6}$ generations and were sampled every 100 generations. The burn-in period discarded 1000 generations. Posterior clade probabilities were used to assess nodal support. Tree topology is represented on the $50 \%$ majority-rule consensus trees.

\subsection{Cytological preparations}

\subsubsection{Light microscopy}

Malpighian tubules, midgut and fat body tissues from infected hosts were individually smeared on slides, observed under phase-contrast microscopy (Olympus IX71), and photographed using a CCD (Olympus DP70) camera. Spore size was measured by Amira 3.1.1 program (for MacOSX).

\subsubsection{Transmission electron microscopy}

The infected tissues were fixed for 2 weeks in $5 \%$ glutaraldehyde in a $0.1 \mathrm{M}$ phosphate buffer ( $\mathrm{pH} 7.2$ ) and postfixed in $1 \% \mathrm{OsO}_{4}$ for $2 \mathrm{~h}$ (Wang et al., 2005). The tissues were then dehydrated in an ethanol gradient series and the samples were embedded in EMBed 812 (Electron Microscopy Sciences). Thin sections were cut on a Reichert OMU 3 ultramicrotome and stained with uranyl acetate and lead citrate. The micrographs were taken with a Hitachi $\mathrm{H} 7100$ electron microscope operated at an accelerating voltage of $80 \mathrm{kV}$.

\section{Results}

\subsection{Gross pathology}

In the early stages of infection, there were no obvious signs or symptoms of disease. In the late stages, the infected larvae showed obvious signs, including changing of body color from brown to light yellow-brown and increasing transparency of the abdominal integument. In addition, the infected larvae exhibited symptoms such as vomiting and diarrhea. Microsporidian spores could be observed using phase-contrast microscopy in the fluid vomit and feces. In the late stages, the entire gut of infected larvae was swollen, light yellow-brown in color, and filled with fluid. The Malpighian tubules were white to light pink, and the fat body was atrophied. Eventually, the larvae died, with the soft tissues gathered to the posterior half of the body producing a balloon-like appearance.

\subsection{Phylogenetic analysis of SSUrDNA}

The SSUrDNA gene of Vairimorpha ocinarae consisted of $1248 \mathrm{bp}$, and the GC content was $36.78 \%$. Based on SSUrDNA sequences, two genera, Vairimorpha and Nosema, formed a complex in the maximum likelihood analysis (Fig. 1). V. ocinarae was unique and shared the same ancestor with other species within the Vairimorpha complex. The identities of SSUrDNA sequences between $V$. ocinarae and other species within the Vairimorpha complex were 96-98\%. Identity between $V$. ocinarae and the type species of the genus, Vairimorpha necatrix, was $96 \%$. The identities between $V$. oci- 


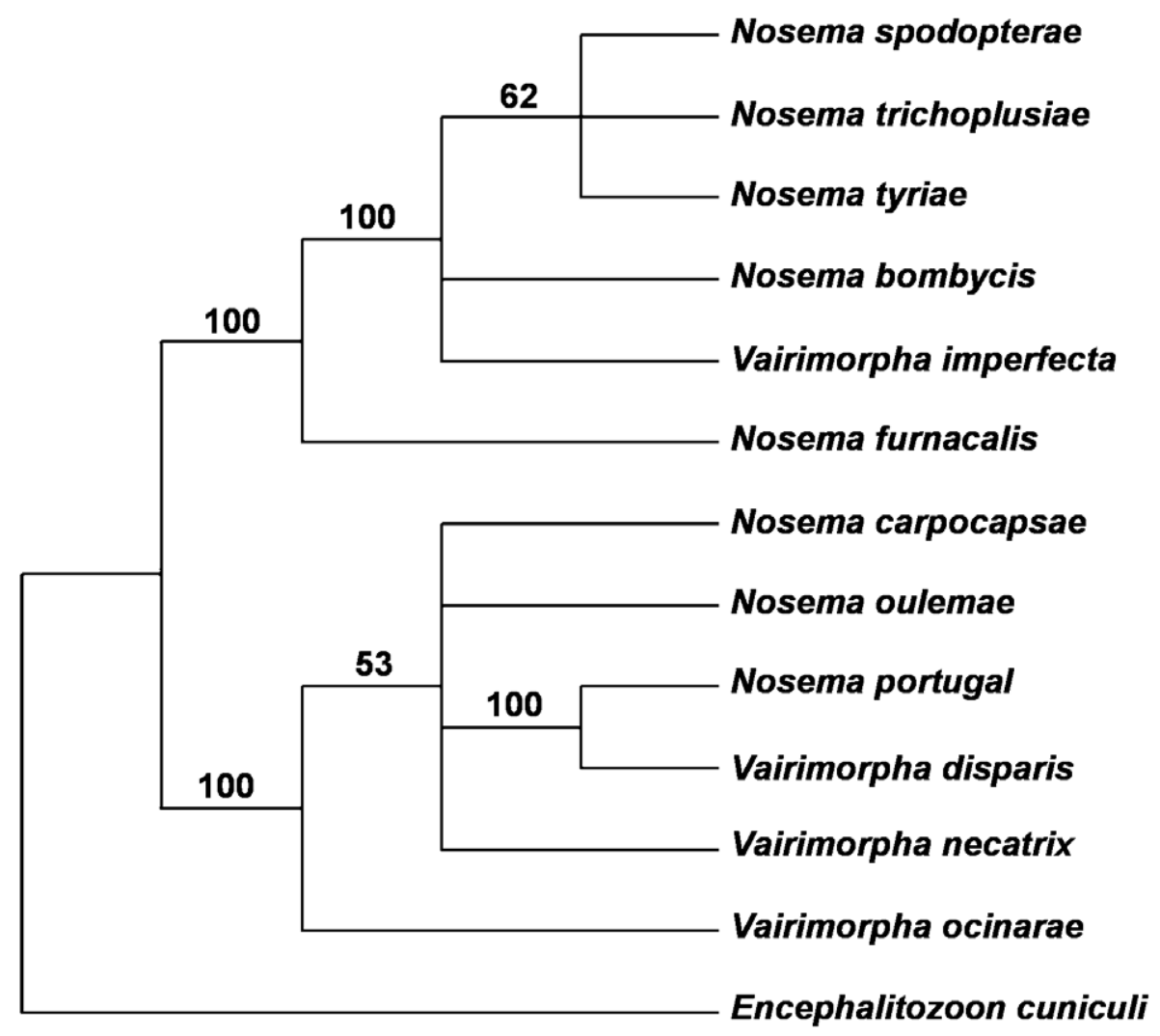

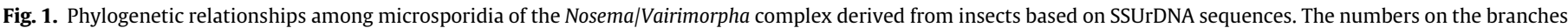

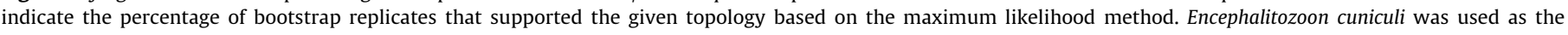
outgroup.

narae and Nosema species within Vairimorpha complex were 97$98 \%$, but were $81-82 \%$ between $V$. ocinarae and species within the 'true' Nosema complex (type species Nosema bombycis. All Vairimorpha species analyzed were parasites of lepidopteran insects with the exception of $N$. oulemae, which was isolated from a coleopteron. The distance matrix is shown in Table 2 . The shortest distance was found between $V$. ocinarae and $N$. carpocapsae.

\subsection{Morphological characteristics}

\subsubsection{Light microscopy}

Because the host larvae were infected transovarially, the primary sporulation cycle (S1 cycle; Vavra et al. 2006) reported in most recent Nosema and Vairimorpha species descriptions was not observed. The fresh single diplokaryotic spores of the secondary sporulation cycle (S2ss) were elongate-oval in shape, refractive under phase-contrast microscopy (Fig. 2), and abundant in the epithelium of midgut and Malpighian tubules. Fresh, mature S2ss spores measured $4.17 \pm 0.25 \times 2.34 \pm 0.13 \mu \mathrm{m}$ (mean \pm standard error, $n=50$ ). Octospores produced in the octosporous secondary sporulation cycle (S2oct) were found in the midgut muscles (Fig. 3) and fresh mature spores measured $2.62 \pm 0.3 \times 1.39 \pm 0.18 \mu \mathrm{m}$. Cyst-like structures $(33.55-48.19 \mu \mathrm{m}$ in diameter) (Fig. 4) were commonly seen in the gut tissues but not in other tissues. We were not able to determine if these structures were actually cysts or were individual cells filled completely with spores.

\subsubsection{Transmission electron microscopy}

3.3.2.1. Diplokaryotic secondary spore sporulation cycle (S2ss). The microsporidium completed the S2ss cycle in direct contact with the host cell cytoplasm in all tissues, primarily in the gut epithelial tissues and the Malpighian tubules. All developing stages were observed in these tissues, however, asynchronous development of $V$. ocinarae in individual infected cells was observed. In the early stage of S2ss merogony (Fig. 5), the meront was round in shape and possessed a homogenous light-staining cytoplasm. No dominant endoplasmic reticulum (ER) or Golgi vesicles were observed in the cytoplasm. Host mitochondria were observed surrounding microsporidia in the early merogonial stage. In the late stage of S2ss merogony, the meront cytoplasm was filled with ER structures (Fig. 6). The S2ss meront then divided into two diplokaryotic

Table 2

Distance matrix for species in the Vairimorpha complex.

\begin{tabular}{|c|c|c|c|c|c|c|c|}
\hline & $\mathrm{Nb}$ & Nc & No & Np & Vd & Vn & Vo \\
\hline $\mathrm{Nb}$ & - & 0.1794486 & 0.18086365 & 0.17966262 & 0.18728919 & 0.17866592 & 0.17926477 \\
\hline Nc & & - & 0.01002917 & 0.01676685 & 0.02273555 & 0.01761634 & 0.01507825 \\
\hline No & & & - & 0.01843923 & 0.02443773 & 0.02271325 & 0.01844851 \\
\hline $\mathrm{Np}$ & & & & - & 0.00582450 & 0.02784010 & 0.02185070 \\
\hline $\mathrm{Vd}$ & & & & & - & 0.03390316 & 0.02786494 \\
\hline Vn & & & & & & - & 0.02872264 \\
\hline Vo & & & & & & & - \\
\hline
\end{tabular}

Nb, Nosema bombycis; Nc, Nosema carpocapsae; No, Nosema oulemae; Np, Nosema portugal; Vd, Vairimorpha disparis; Vn, Vairimorpha necatrix; Vo, Vairimorpha ocinarae. 


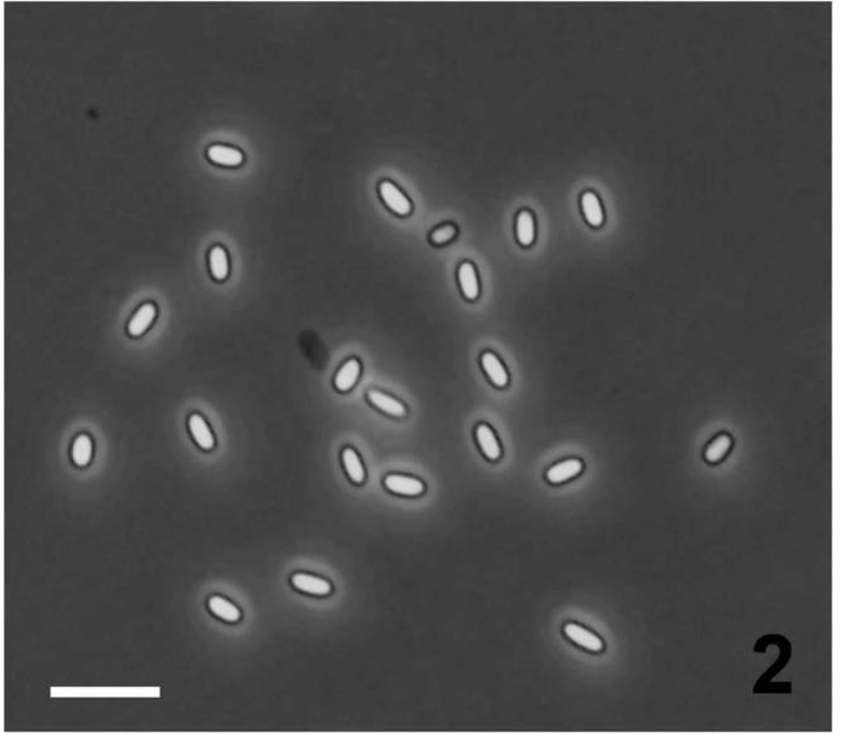

Fig. 2. Light micrographs of Vairimorpha ocinarae showing free diplokaryotic spores. Scale bar, $10 \mu \mathrm{m}$.

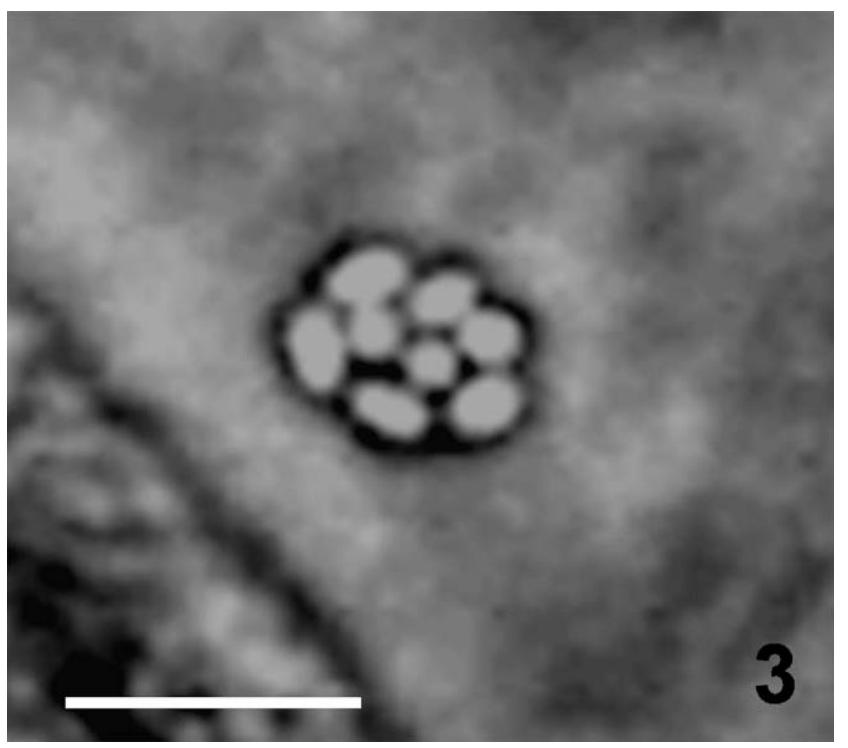

Fig. 3. A sporophorous vesicle containing octospores in the midgut muscle. Scale bar, $10 \mu \mathrm{m}$.

sporonts by binary fission (Fig. 7). A thickened plasmalemma surrounded the S2ss sporonts and obvious ER structures were observed (Fig. 8).

The exospore of the mature S2ss spore (Fig. 9) presented as an undulating electron-dense layer, $24.4 \mathrm{~nm}$ thick on average. The endospore was an electron-lucent layer $77.7 \mathrm{~nm}$ thick on average, except at the anterior part of the spore. The anchoring disc and straight portion of the polar tube formed a mushroom-shaped structure at the anterior part of the spore. The polaroplast was not well fixed for transmission electron microscopy but was observed to be divided into two parts. The anterior portion was more electron-dense than the posterior portion (observed directly behind the lobes of the anterior portion). Many small bubble-like forms (63.7-69.7 $\mathrm{nm}$ in diameter) were observed in the posterior vacuoles (Fig. 10). The polar tube was isofilar with 11-13 coils (typically 12 coils) arranged in a single row. The diameter of the

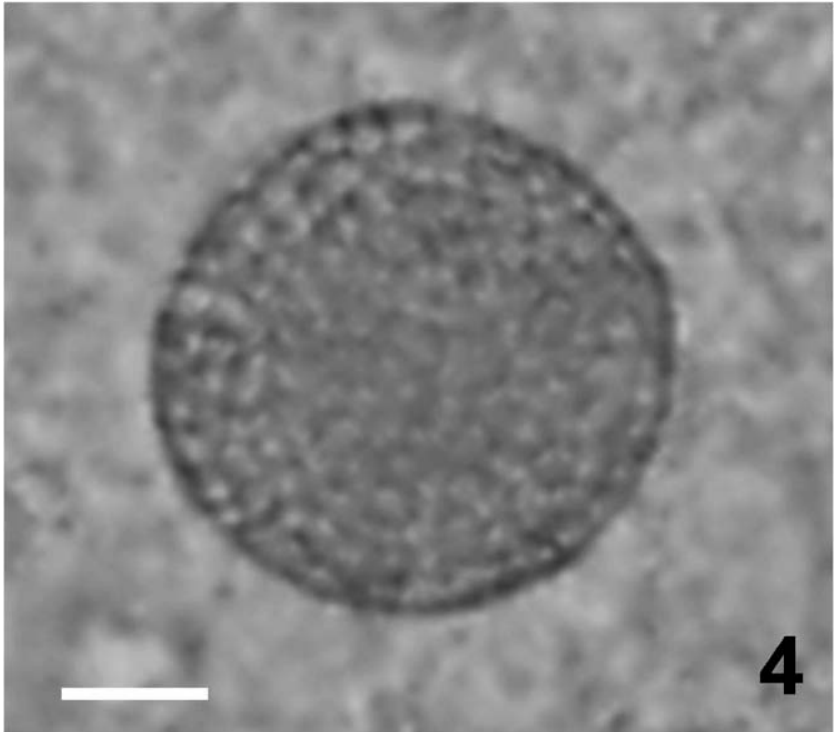

Fig. 4. Cyst-like structure filled with spores in the gut tissues. Scale bar, $10 \mu \mathrm{m}$.

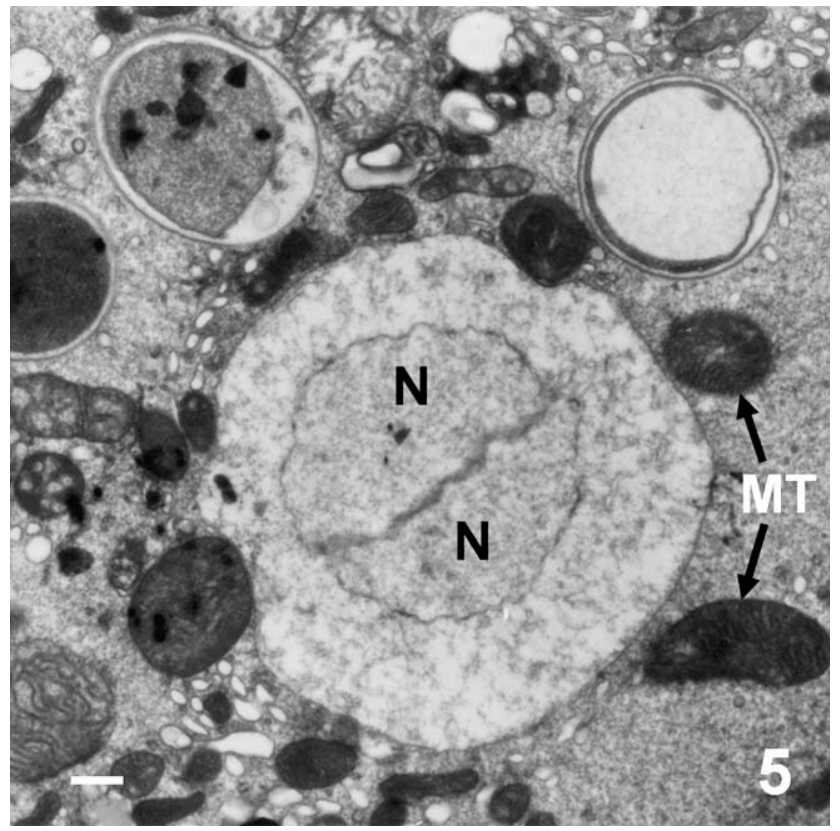

Fig. 5. Transmission electron micrographs of secondary single (diplokaryotic) sporesporulation cycle (S2ss) of Vairimorpha ocinarae. An electron-lucent binucleate S2ss meront surrounded by host mitochondria (MT). N, nucleus. Scale bar, $500 \mathrm{~nm}$.

polar tube was $90.8 \pm 7.4 \mathrm{~nm}$, and many concentric layers were seen in transverse sections (Fig. 11).

3.3.2.2. Octosporous secondary sporulation cycle (S2oct). The octospores produced in the S2oct cycle were observed only in the muscle tissue of alimentary canal, and were not found in the midgut epithelium or Malpighian tubules. In the muscle tissues, the microsporidium primarily exhibited the S2oct sequence rather than the S2ss sequence, but all stages of the two different sequences could be observed in these tissues. In the initial stage of the S2oct cycle, a binucleate sporont was surrounded by a thin, electron-dense envelope to form a sporophorous vesicle (SV). The cytoplasm of the S2oct sporont was rich in ER and aggregated ribosomes (Fig. 12). Electron-dense granules were accumulated in the episporontal 


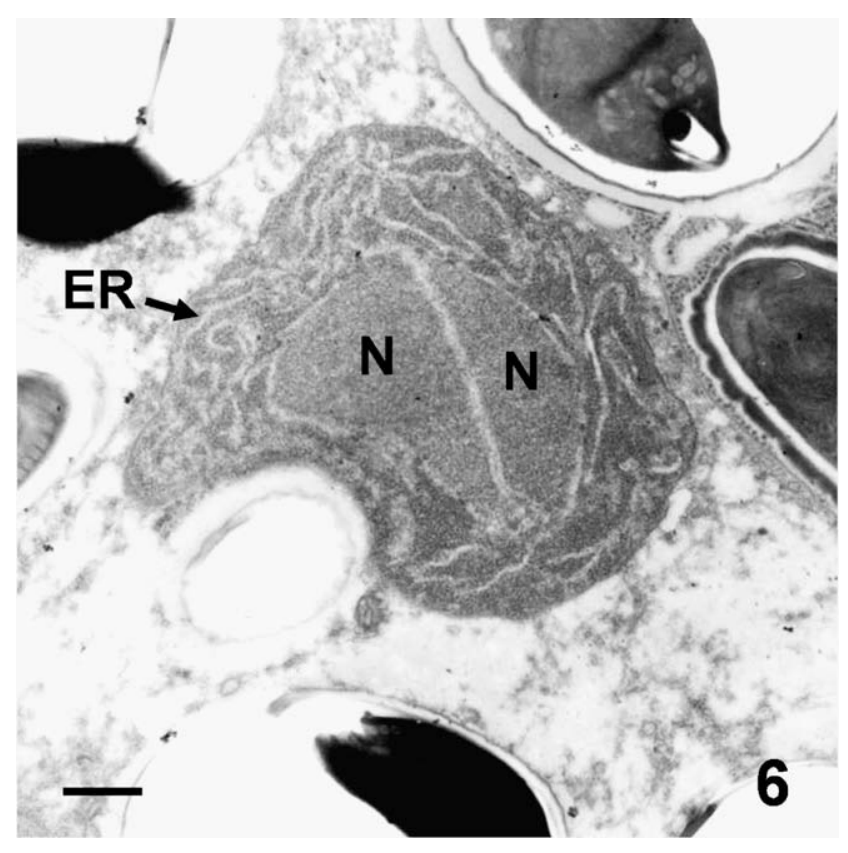

Fig. 6. Transmission electron micrographs of secondary single (diplokaryotic) sporesporulation cycle (S2ss) of Vairimorpha ocinarae. Electron-moderate binucleate S2ss meront showing the dispersed endoplasmic reticulum (ER) in the cytoplasm. N, nucleus. Scale bar, $500 \mathrm{~nm}$.

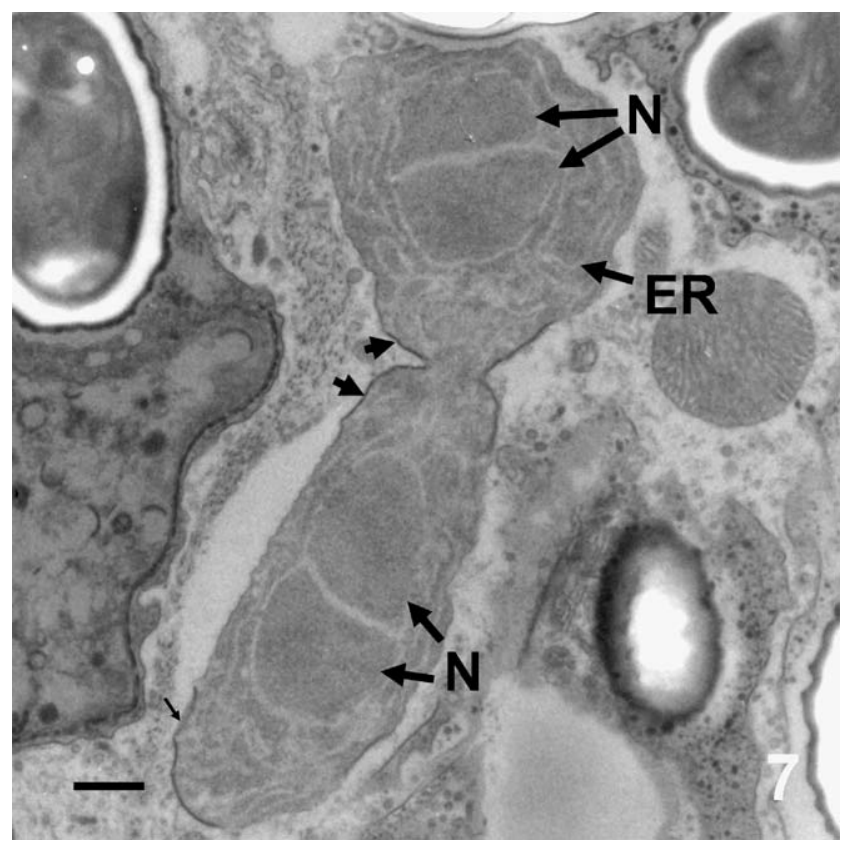

Fig. 7. Transmission electron micrographs of secondary single (diplokaryotic) sporesporulation cycle (S2ss) of Vairimorpha ocinarae. Dividing binucleate S2ss meront with thickened plasmalemma (arrows). N, nucleus. Scale bar, $500 \mathrm{~nm}$.

space, the space between the parasite and the SV envelope, and electron-lucent tubule-like structures were interspersed among the granules (Fig. 12). The binucleate S2oct sporont divided to form uninucleate sporonts, each surrounded by a thin plasmalemma (Fig. 13).

Two stages of plasmodia were observed within the SV and appeared to have different structures: (1) plasmodia with loosely stacked lamellae in the episporontal space: the plasmalemma of the plasmodia extruded large quantities of electron-lucent tu-

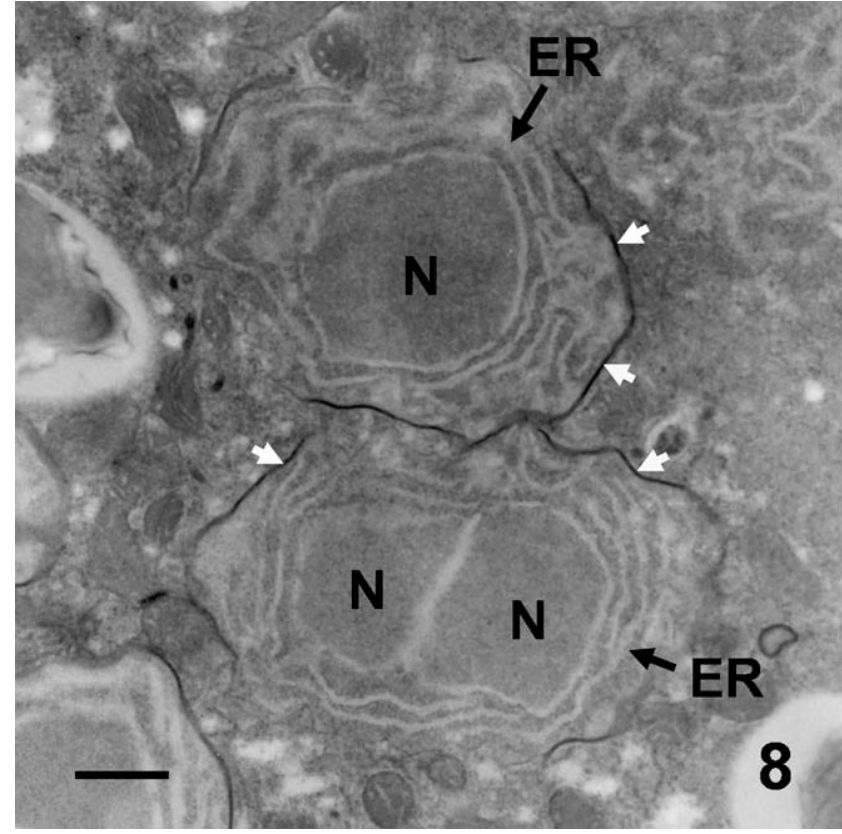

Fig. 8. Transmission electron micrographs of secondary single (diplokaryotic) sporesporulation cycle (S2ss) of Vairimorpha ocinarae. Separated binucleate S2ss sporonts covered with a thickened plasmalemma (arrows) possess electron-dense cytoplasm and dispersed ER. N, nucleus. Scale bar, $500 \mathrm{~nm}$.

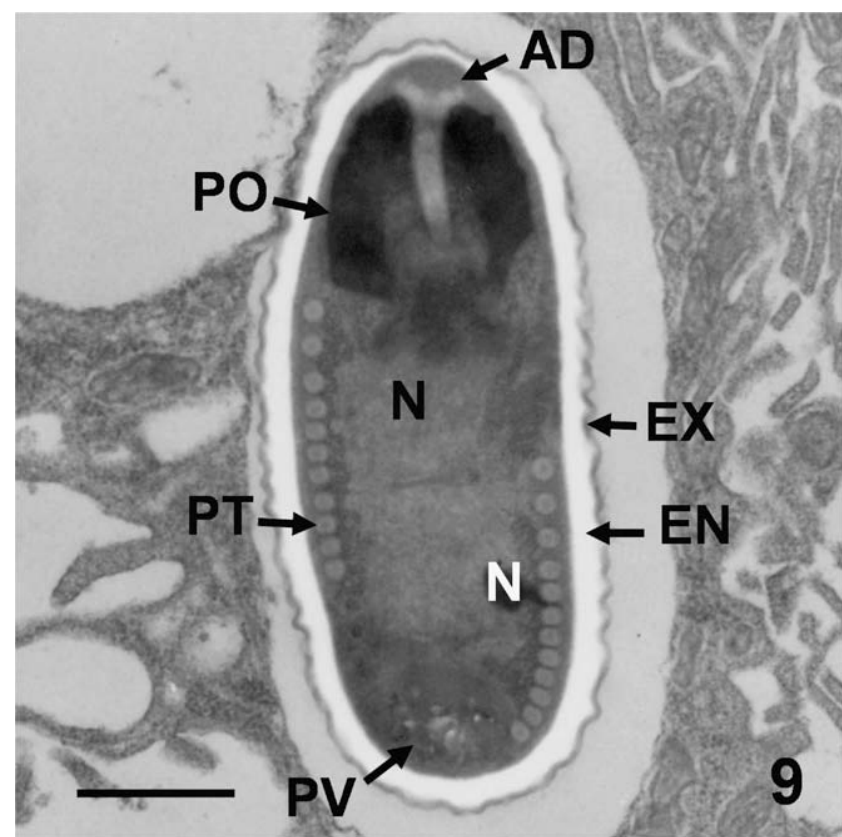

Fig. 9. Transmission electron micrographs of secondary single (diplokaryotic) sporesporulation cycle (S2ss) of Vairimorpha ocinarae. Mature diplokaryotic S2ss spore showing anchoring disc (AD), polaroplast (PO), polar tube (PT), posterior vacuole (PV), exospore (EX), and endospore (EN). N, nucleus. Scale bar, $500 \mathrm{~nm}$.

bule-like structures (Fig. 14) that formed channels from the S2oct sporonts to the host cytoplasm (Fig. 14A and B); and (2) multinuclear plasmodia with the thin plasmalemma enveloped by an outside electron-dense layer. Tubule-like structures budded from the plasmalemma, and the distal ends of these electron-dense tubule-like structures were covered with another electron-dense substance (Fig. 15A and B). In cross-section, the tubules were $75.4 \mathrm{~nm}$ in diameter (Fig. 15B). In this plasmodial form, electron- 


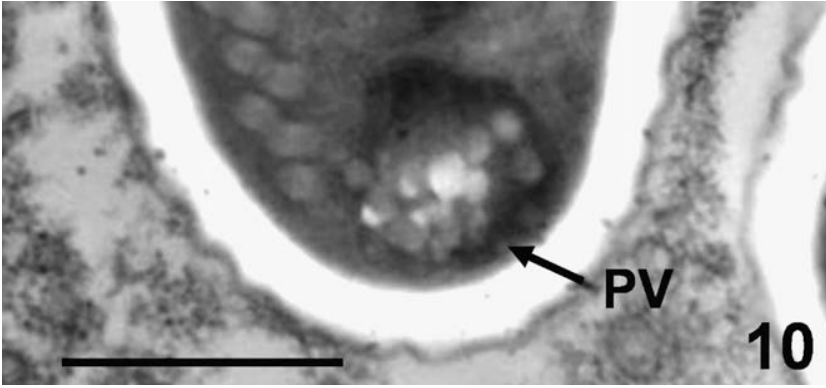

Fig. 10. Transmission electron micrographs of secondary single (diplokaryotic) sporesporulation cycle (S2ss) of Vairimorpha ocinarae. Posterior vacuole with small bubble-like forms. N, nucleus. Scale bar, $500 \mathrm{~nm}$.

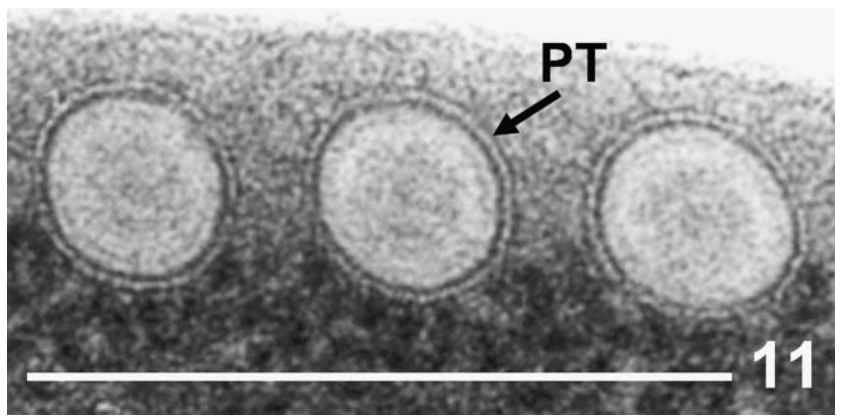

Fig. 11. Transmission electron micrographs of secondary single (diplokaryotic) sporesporulation cycle (S2ss) of Vairimorpha ocinarae. The polar tube consists of many concentric coils. N, nucleus. Scale bar, $500 \mathrm{~nm}$.

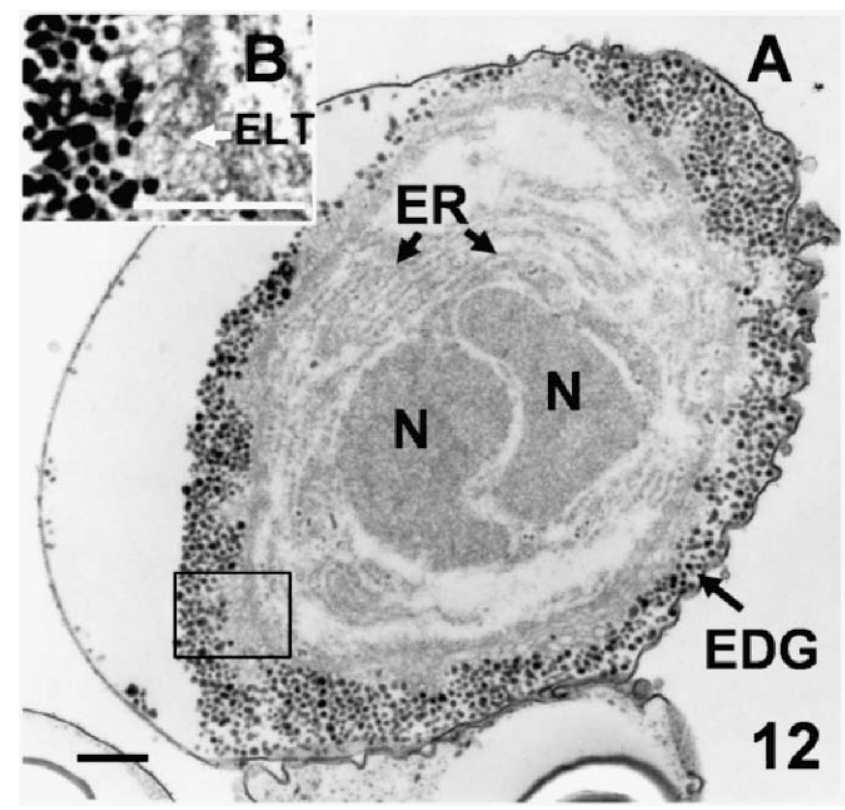

Fig. 12. Electron micrographs of Vairimorpha ocinarae in the early stages of octosporous secondary sporulation cycle (S2oct). Binucleate S2oct sporont: (A) episporontal space (EpS) filled with electron-lucent tubules (ELT) and electrondense granules (EDG); (B) highly magnified photograph showing the tubular structures of ELT. Scale bar, $500 \mathrm{~nm}$.

lucent tubules also formed channels connecting to the host cytoplasm (Fig. 15A).

The S2oct sporonts were enveloped by electron-dense layers and each lobe contained one nucleus (Fig. 16). A few large and reg-

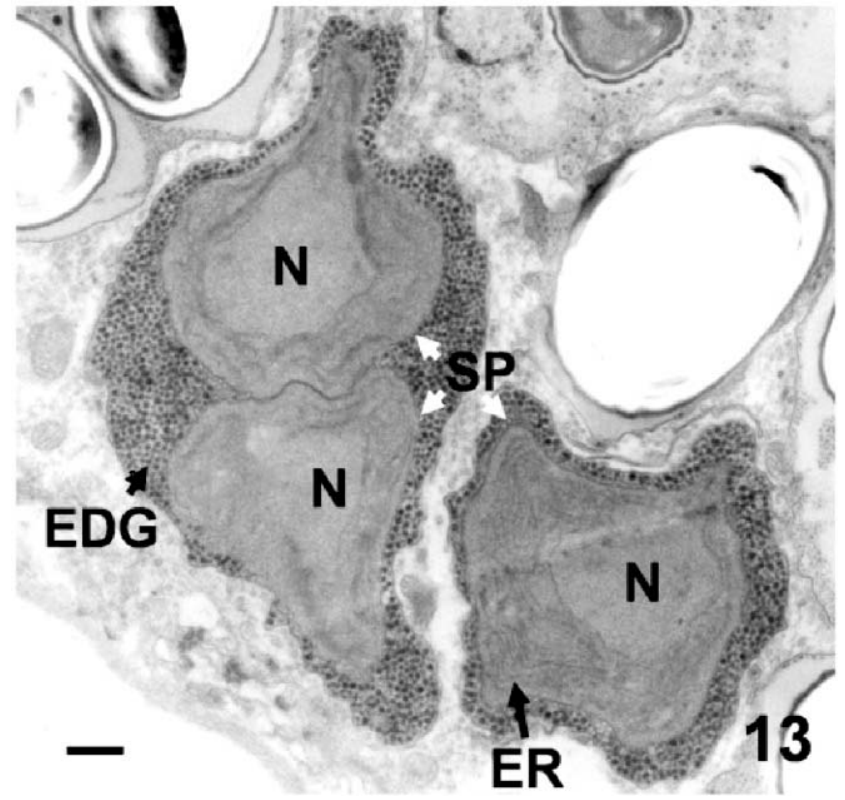

Fig. 13. Electron micrographs of Vairimorpha ocinarae in the early stages of octosporous secondary sporulation cycle (S2oct). Two sporophorous vesicles containing three visible monokaryotic sporonts (SP). Scale bar, $500 \mathrm{~nm}$.

ular electron-dense granules were surrounded with lamellae in the episporontal space (Fig. 17). Irregularly shaped S2oct sporoblasts were observed in the SVs, and the number of electron-dense granules apparently decreased in the episporontal space during development of sporoblasts (Fig. 18). The sporoblast (Fig. 19A) possessed an electron-dense coat with a sandwiched structure consisting of a thin electron-moderate outer-layer $(8.3 \mathrm{~nm})$, a thick electron-dense mid-layer $(58.6 \mathrm{~nm})$, and an electron-lucent innerlayer $(16.3 \mathrm{~nm})$ (Fig. 19A). Lamella-like structures $(35.6 \mathrm{~nm})$ formed within the SV during this period consisted of three layers, two electron-moderate layers of approximately equal thickness sandwiching a very thin electron dense layer (6.1 nm) (Fig. 19B). In addition, the developing polar tube was observed. Unsynchronized development of S2oct sporoblasts in the same SV was also observed (Fig. 19). In the later sporoblastic stage, irregular groups of transversely sectioned coils of polar tube were arranged at the mid-posterior area of the sporoblasts, and a large empty space surrounded each sporoblast within the SV, possibly due to shrinkage in size of the maturing spores (Fig. 20). The mature octospore possessed a three-layer arrangement of polar tube coils (8-9 coils), one nucleus, the polaroplast, and a thick spore wall including an electron-lucent, thick endospore wall approximately 84-125 nm thick, and an undulating layered thin exospore wall approximately $34 \mathrm{~nm}$ thick (Fig. 21).

\section{Discussion}

Two genera of microsporidia, an Endoreticulatus species from Taiwan that is closely related to E. schubergi (Wang et al., 2005), and $V$. ocinarae described in this study, have been isolated from o. lida collected from different sites in Taiwan. The two microsporidian isolates are easily differentiated based on the number of nuclei contained in the mature spores, tissue tropism, and molecular sequence (SSUrDNA). V. ocinarae produces both diplokaryotic single spores and monokaryotic octospores in a sporophorous vesicle, and infection is systemic in the host. In contrast, Endoreticulatus sp. infects only midgut tissues, is uninucleate in all stages, and devel- 

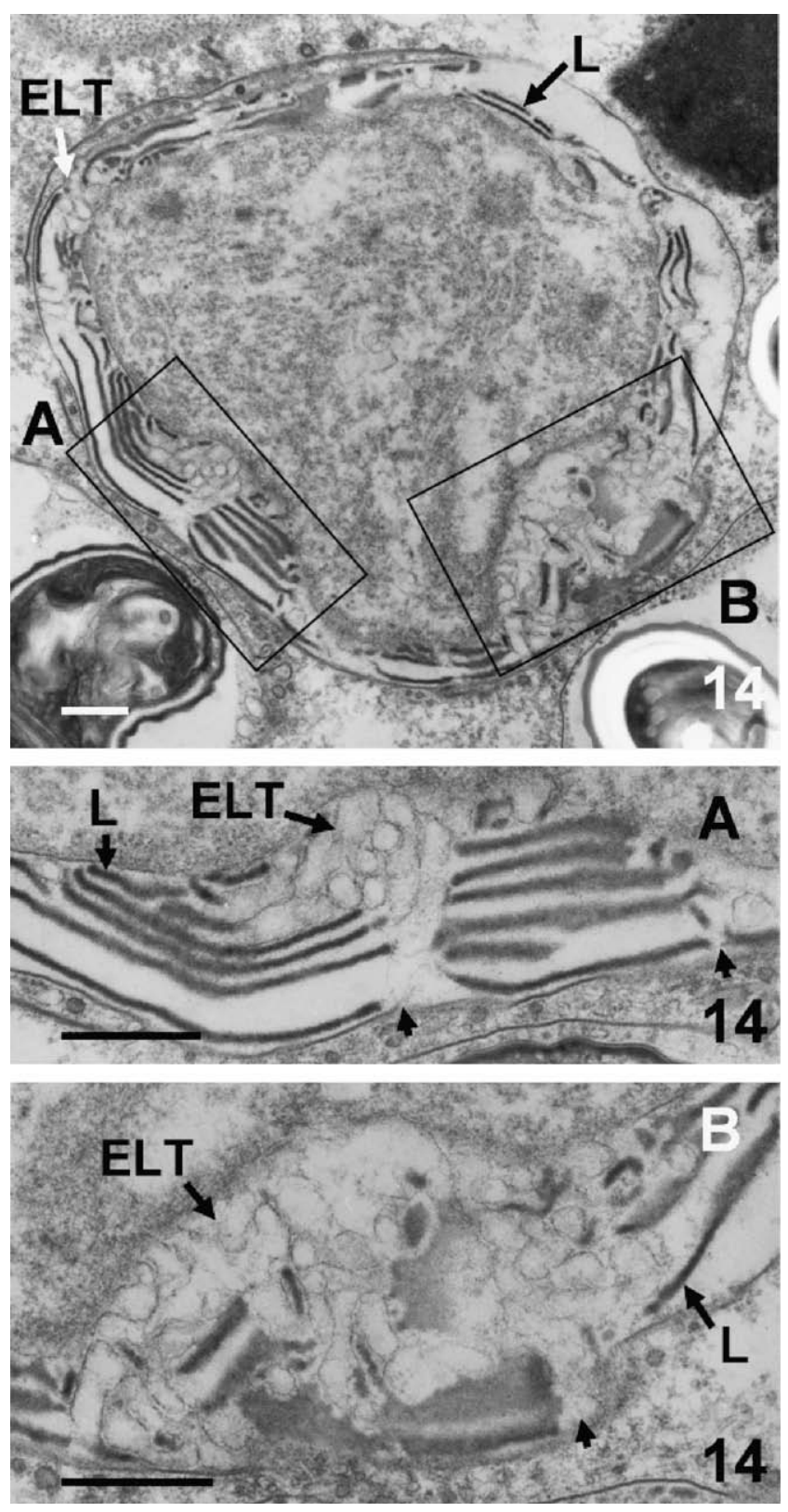

Fig. 14. Plasmodium of Vairimorpha ocinarae surrounded by loosely stacked, fragmented lamellae (L) in the episporontal space. (A and B) two highly magnified micrographs showing electron-lucent tubules (ELT) that interrupt the lamellae (A) and ELT that originate from the plasmalemma (PL) to the sporophorous vesicle membrane (arrows) (A and B). Scale bar, $500 \mathrm{~nm}$.

ops in a parasitophorous vesicle. It is not uncommon to recover microsporidia from different genera in the same host; for example, microsporidian species belonging to the genera Endoreticulatus, Nosema, and Vairimorpha were isolated from different populations of Lymantria dispar in Bulgaria (Solter et al., 2000) and other areas in Eastern and Central Europe (McManus and Solter, 2003).

The gross pathology of $V$. ocinarae differs appreciably from those of other lepidopteran Vairimorpha spp., including atrophy of the fat body tissues, swelling of gut tissues, and whitish to pink color of the Malpighian tubules. Typically, the fat body is the primary target tissue for lepidopteran Vairimorpha species, and cells are often hypertrophic and filled with both diplokaryotic spores and octospores (Canning et al., 1999; Darwish et al., 1989; Mitchell and Cali, 1993; Moore and Brooks, 1992; Moore and Brooks, 1994), unlike the fat body atrophy observed in $V$. ocinarae infections.
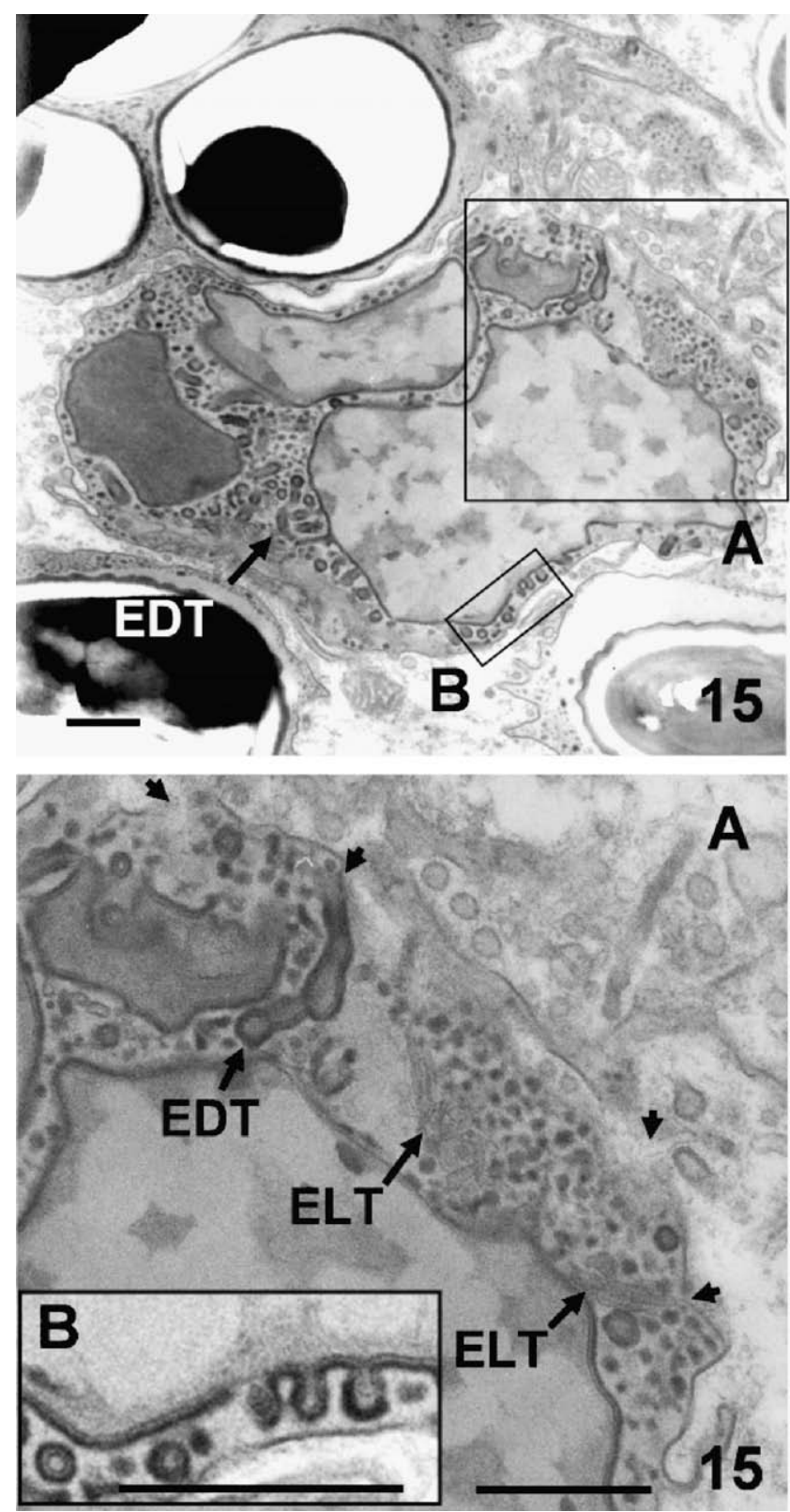

Fig. 15. A plasmodium of Vairimorpha ocinarae containing multiple nuclei and electron-dense tubules (EDT) on the surface of plasmodium. (A) and (B) two highly magnified photographs showing ELT and helical EDT that form pathways from parasite to the cytoplasm of host cell (A), and budded EDT from the parasite plasmalemma (B). Scale bar, $500 \mathrm{~nm}$.

The developmental stages of $V$. ocinarae were similar to many Vairimorpha species but episporontal inclusions of $V$. ocinarae were different from those of other Vairimorpha species (Table 3). Vairimorpha species have been reported to include different types of episporontal inclusions (granules), electron-dense stacked lamellae, and irregular meshwork within the episporontal space of the sporophorous vesicle (Canning et al., 1999; Mitchell and Cali, 1993; Moore and Brooks,1992, 1994; Vavra et al., 2006). V. ocinarae produces a simple type of episporontal inclusions in the form of electron-dense granules, similar to those of $V$. invictae (Jouvenaz and Ellis, 1986). Large granules were observed in both $V$. ocinarae and $V$. invictae, but the tri-layer structure of the granules is described only for $V$. ocinarae (Fig. 18).

The granules of $V$. ocinarae accumulated and formed a few lamellae (Fig. 15), but they did not develop into an amorphous 


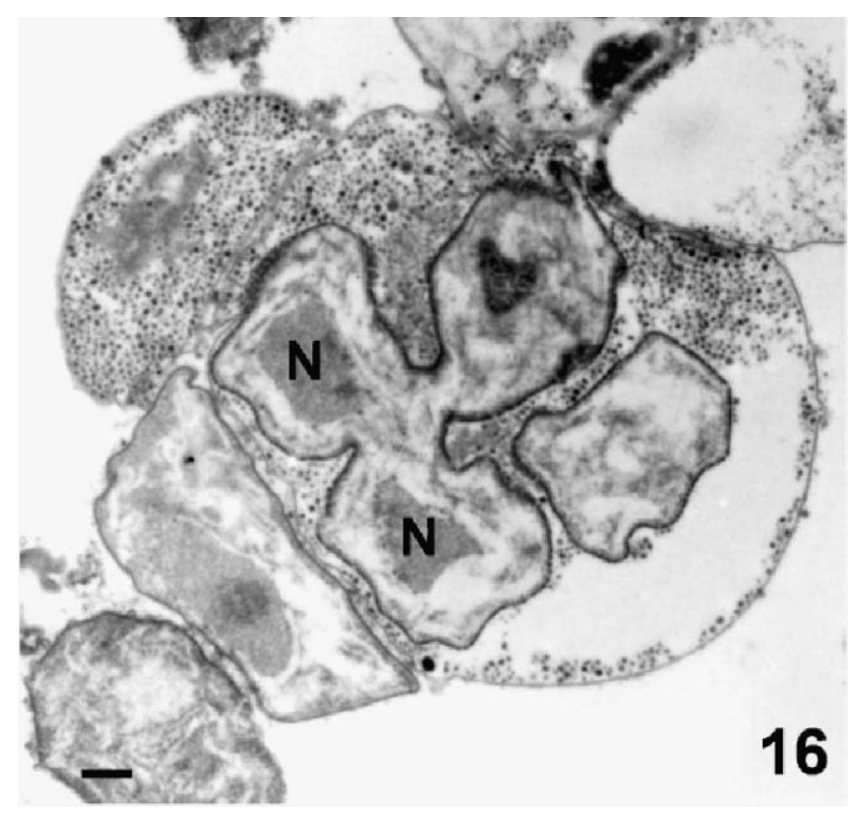

Fig. 16. Electron micrographs of Vairimorpha ocinarae in the middle and late stages of octosporous sporulation (S2oct) cycle. A lobed S2oct sporont with one nucleus $(\mathrm{N})$ in each lobe. Scale bar, $500 \mathrm{~nm}$.

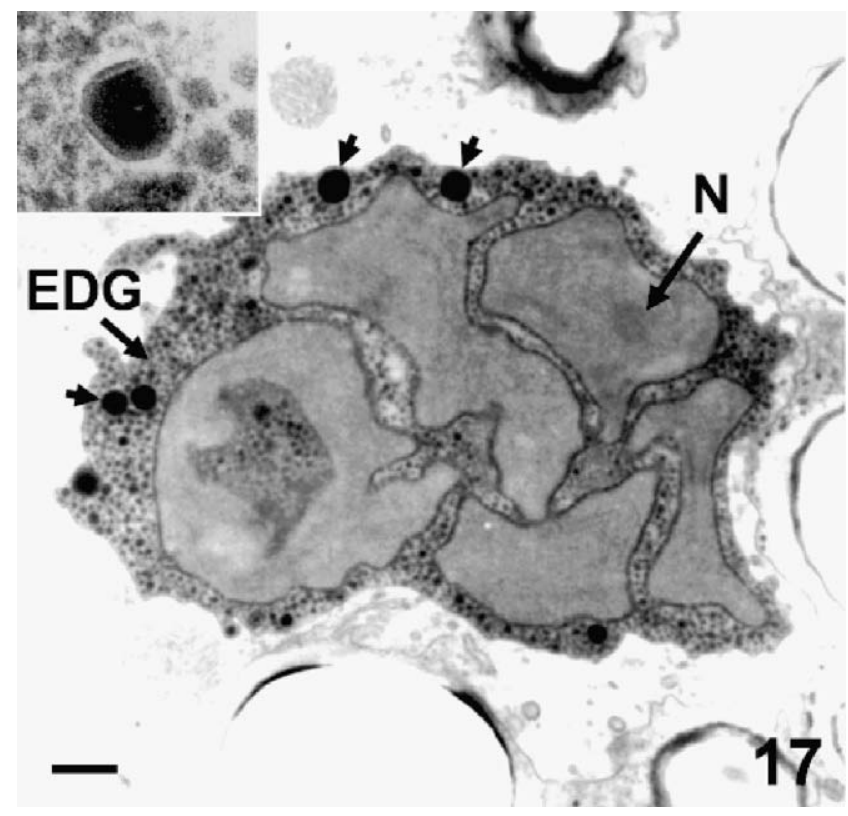

Fig. 17. Electron micrographs of Vairimorpha ocinarae in the middle and late stages of octosporous sporulation (S2oct) cycle. Five sporoblasts surrounded with electron-dense granules (EDG) in the sporophorous vesicle. Highly magnified photograph (left corner) shows large electron-dense granules (EDG) coated with lamellae (arrows). Scale bar, $500 \mathrm{~nm}$.

mass or meshwork like that observed in $V$. necatrix (Moore and Brooks, 1992; Mitchell and Cali, 1993), V. disparis (Vavra et al., 2006), and $V$. heterosporum (Moore and Brooks, 1994). Moore and Brooks (1994) proposed that episporontal inclusions may be used as taxonomic features among species. In our case, episporontal inclusions of $V$. ocinarae are actually different from other related Vairimorpha species. Although $V$. invictae possesses similar electron-dense granules, its spore size $(11.2 \times 3.1 \mu \mathrm{m})$ and polar tube coils (24-26 coils) are different from $V$. ocinarae (Jouvenaz and Ellis, 1986). Due to the low genetic identity between $V$. invictae and

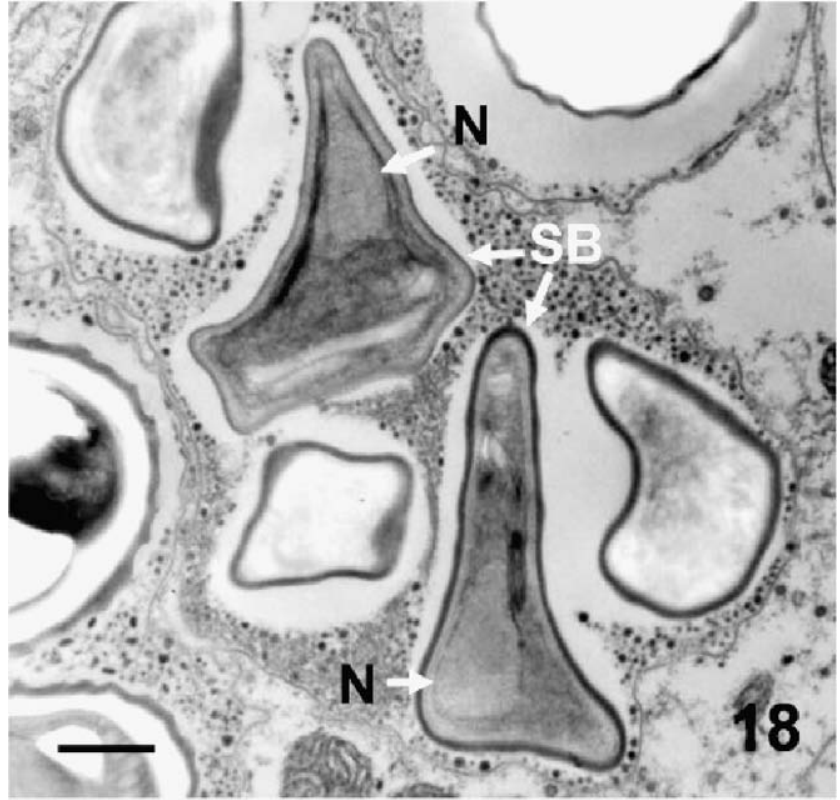

Fig. 18. Electron micrographs of Vairimorpha ocinarae in the middle and late stages of octosporous sporulation (S2oct) cycle. Monokaryotic sporoblasts (SB) with a smooth, electron-dense and thickened exospore. Scale bar, $500 \mathrm{~nm}$.

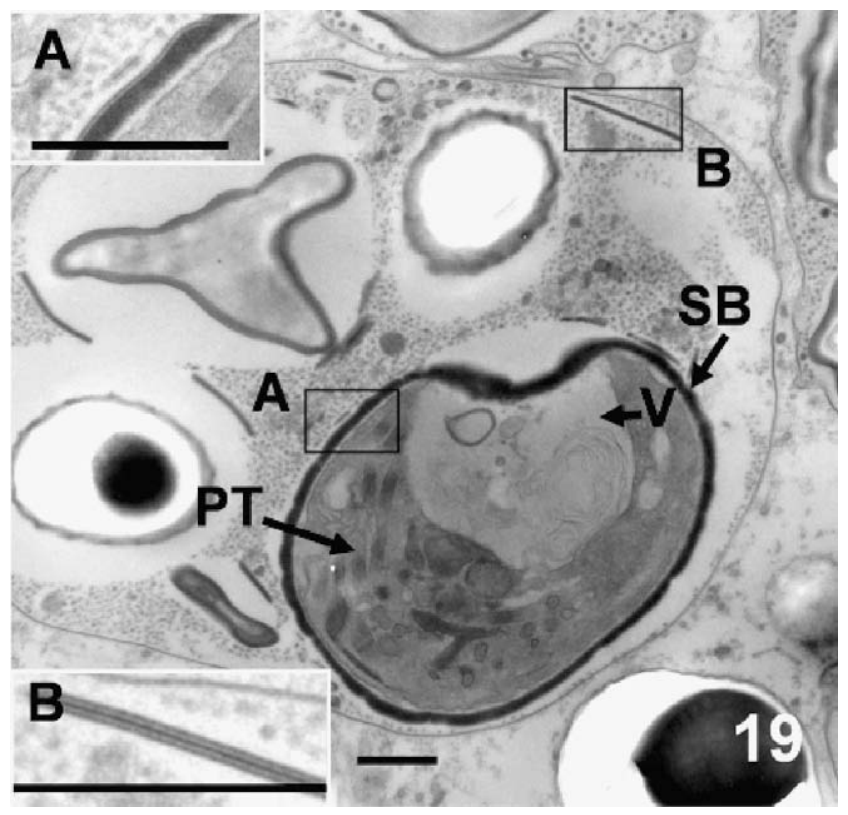

Fig. 19. Electron micrographs of Vairimorpha ocinarae in the middle and late stages of octosporous sporulation (S2oct) cycle. Sporoblast with electron-dense thick exospore, polar tube primordia (PT), and large vacuole (V). Lamellae are found in episporontal spaces. Enlarged micrograph shows two layers of the exospore, a thin electron-lucent and a thick electron-dense layer (A), and a lamella with electrondense line in the center in the episporontal space (B). Scale bar, $500 \mathrm{~nm}$.

$V$. ocinarae, $V$. invictae was not analyzed in the phylogenetic tree of SSUrDNA. It was previously shown that $V$. invictae is not closely related to other Vairimorpha species, including V. necatrix (Moser et al., 1998).

The correlation between episporontal inclusions and phylogenetic relationships among species in the Nosema/Vairimorpha complex is probably low. $V$. imperfecta exhibits an abortive octosporous sporogony, and produces electron-dense tubules and network of electron-dense materials in the episporontal space (Canning 


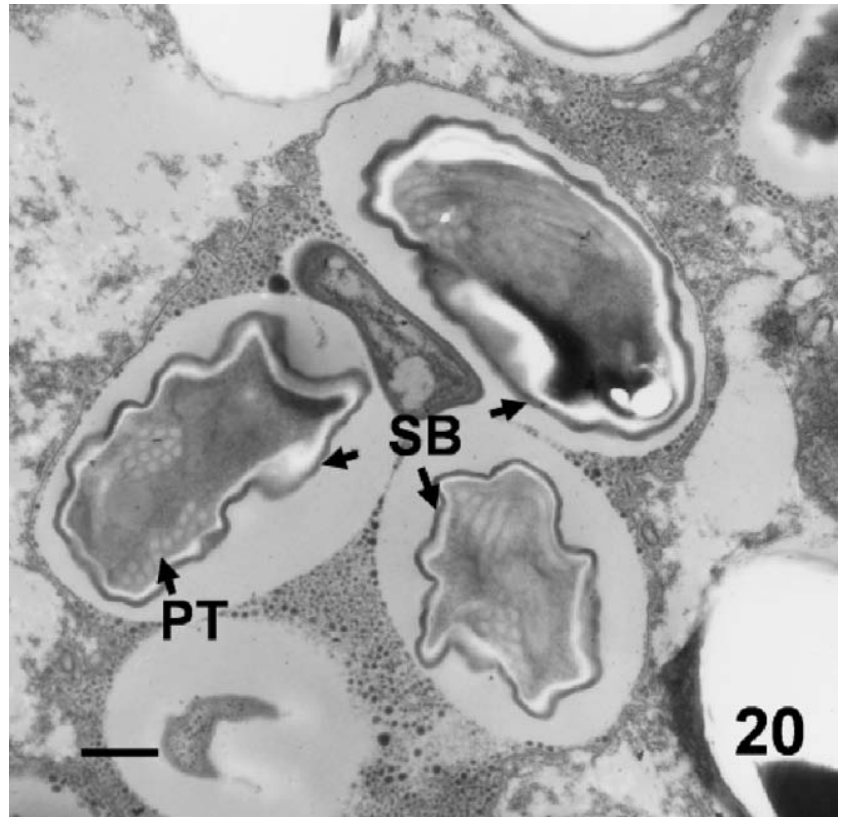

Fig. 20. Electron micrographs of Vairimorpha ocinarae in the middle and late stages of octosporous sporulation (S2oct) cycle. Sporoblasts showing thickened endospore and irregular groups of transversely sectioned coils of polar tubes (PT) in the parasite. Scale bar, $500 \mathrm{~nm}$.

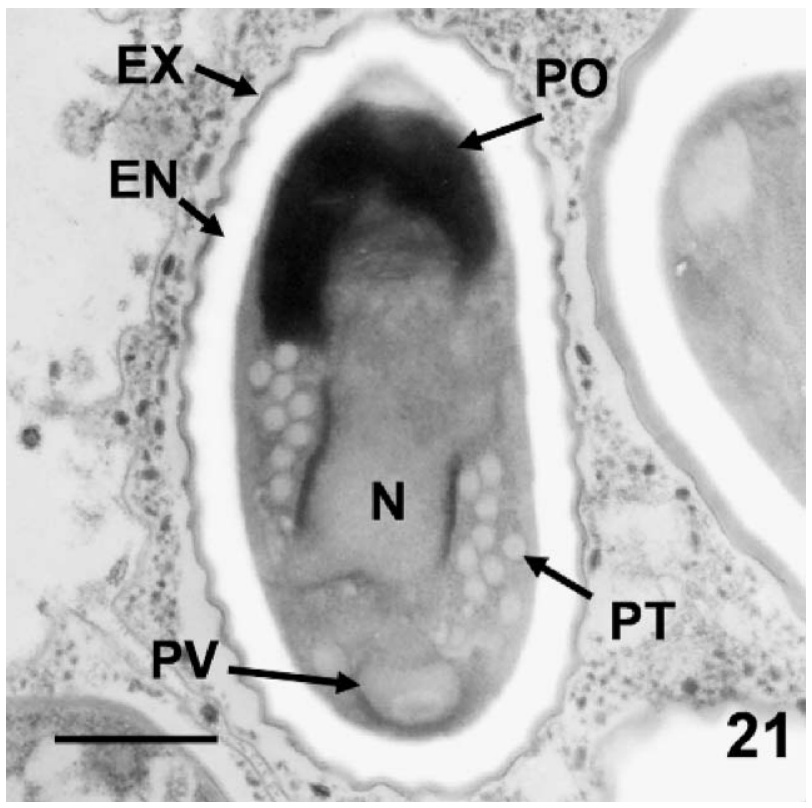

Fig. 21. Electron micrographs of Vairimorpha ocinarae in the middle and late stages of octosporous sporulation (S2oct) cycle. Mature octospore with one nucleus (N), endospore (EN), exospore (EX), polaroplast (PO), posterior vacuole (PV) and polar tube (PT). Scale bar, $500 \mathrm{~nm}$.

et al., 1999). $V$. imperfecta was, however, classified in the Nosema complex based on phylogenetic analysis of the SSUrDNA. Although episporontal inclusions may not be a useful morphological character to distinguish the Vairimorpha within the Nosema/Vairimorpha complex, it is possible that they might be used to discriminate among Vairimorpha species.

The electron-lucent tubules and the electron-dense tubules found in V. ocinarae were also reported for other Vairimorpha species (Canning et al., 1999; Moore and Brooks,1992, 1994). The elec- tron-dense tubules of $V$. ocinarae extended from the plasmodial surface and terminated beneath the SV envelope. They followed a slightly helical course and may play a role in the maintaining the functional link between the parasite and the host cytoplasm, possibly a pathway for nutrients or signal transduction between the parasite and the host cell. In fact, we observed many pores in the SV envelope (Figs. 16A and 17A) that are the openings for the electron-dense tubules. Similarly, it was reported that the pores on the parasitophorous membrane of Encephalitozoon cuniculi may contribute to the exchange of materials between the microsporidium and the host (Rönnebäumer et al., 2008). The electron-dense tubules of $V$. ocinarae were round in cross-section (Fig. 16B), similar to those of other Vairimorpha species (Table 3). Among isolates, this characteristic may present as different types (Moore and Brooks, 1994).

Diplokaryotic (S2ss) spores of $V$. ocinarae were slightly different from those of other Vairimorpha species, including the size of fresh spores and the number of polar tube coils. Small bubble-like forms were observed in the posterior vacuole of diplokaryotic S2ss spores of $V$. ocinarae; similar structures were not reported from other Vairimorpha species. N. portugal possesses similar structures, but these forms were not observed in the closely related $V$. disparis (Maddox et al., 1999; Vavra et al., 2006). The octospores of $V$. ocinarae were smaller in size than those of other Vairimorpha species, and there were fewer polar tube coils (8-9 coils) than observed in other species with the exception of $V$. invictae (9 coils) (Jouvenaz and Ellis, 1986).

The phylogenetic relationships between $V$. ocinarae and other species within the Vairimorpha complex have typically been interpreted based on maximum likelihood and maximum parsimony methods (Fig. 1 and Supplementary data). Analyses showed that $V$. ocinarae is a unique species and distinct from other species in the Vairimorpha complex. The bootstrap values were very high (100\%), but the relationships between other species within Vairimorpha complex were still unclear, except that $N$. portugal and $V$. disparis both pathogens of the gypsy moth, Lymantria dispar (L.) were clustered together. The high identities (96-99\%) among species of Vairimorpha lead to low resolution using different analytical methods (Supplementary data).

In the distance analysis, $V$. ocinarae is closer to $N$. carpocapsae than to other species, but the distance between $N$. carpocapsae and $N$. oulemae $(0.01002917)$ is shorter than the distance between $V$. ocinarae and $N$. carpocapsae (0.01507825). Distances between $V$. ocinarae and other species in Vairimorpha complex were larger (Table 2). The $V$. ocinarae/ $N$. carpocapsae/ $N$. oulemae group, and the $N$. portugal/V. disparis group were separated in the phylogenetic analysis based on neighbor-joining method.

Vairimorpha ocinarae is placed in the genus Vairimorpha based on typical morphological characteristics of Vairimorpha and phylogenetic analyses of its SSUrDNA. This microsporidium was initially hypothesized to be a new Vairimorpha species based on tissue tropism and effects on the host, morphological characteristics and the peculiarities of electron-dense granules in ultrastructural evaluation. The results of phylogenetic analyses corroborate its assignment as a new species.

\subsection{Taxonomic characteristics}

Vairimorpha ocinarae $n$. sp.

\subsubsection{Type host}

Ocinara lida Moore.

\subsubsection{Collection site}

Taipei, Taiwan (12132́23́ East, 2500'36" North). 
Table 3

Comparisons of episporontal inclusions of Vairimorpha species during octosporous secondary sporulation cycle (S2oct).

\begin{tabular}{|c|c|c|c|c|}
\hline Species & Initial inclusion & Late-stage inclusion & Tubules & Reference \\
\hline V. disparts & Mesh-like EP & Mesh-like EP & - & Vavra et al. (2006) \\
\hline V. ephesliae & Lamellae & - & - & Wciscr and Purrini (1985) \\
\hline V. heterosporum & $\begin{array}{l}\text { Dense, amorphous masses enlarging Lo become } \\
\text { vacuolated or vesiculated in appearance }\end{array}$ & Thick lamellae with hinged configurations & $\begin{array}{l}\text { Round, } \\
\text { becoming } \\
\text { coated }\end{array}$ & Moore and Brooks (1994) \\
\hline V. imperfectae & Abortive, mesh-like EP & Abortive, mesh-like EP & $\begin{array}{l}\text { Abortive, } \\
\text { becoming } \\
\text { coated }\end{array}$ & Canning et al. (1999) \\
\hline V. iiwlctae & Electron-dense granules & Electron-dense granules No convoluted layer & - & Jouvenaz and Ellis (1986) \\
\hline V. necatrix & $\begin{array}{l}\text { Amorphous, vacuolated to vesiculated mass; } \\
\text { irregular organized lamellae, later becoming } \\
\text { vacuolated }\end{array}$ & $\begin{array}{l}\text { Stacked, regularly layered lamellae (finger- } \\
\text { print) to mass; reticular lamellae, or finger- } \\
\text { print }\end{array}$ & $\begin{array}{l}\text { Round, } \\
\text { becoming } \\
\text { coated }\end{array}$ & $\begin{array}{l}\text { Moore and Brooks (1992, } \\
\text { 1994), Mitchell and Cali. } \\
\text { (1993) }\end{array}$ \\
\hline V. ocinarae & Electron-dense granules & $\begin{array}{l}\text { Electron-dense granules; stacked, loosely } \\
\text { lamellae }\end{array}$ & $\begin{array}{l}\text { Round, } \\
\text { becoming } \\
\text { coated }\end{array}$ & This study \\
\hline V. ploidae & Thin, irregularly organized lamellae & Whorled, finger-print lamellar pattern & $\begin{array}{l}\text { Round, } \\
\text { becoming } \\
\text { coated }\end{array}$ & Moore and Brooks (1994) \\
\hline
\end{tabular}

\subsubsection{Site of infection}

Systemic infection. Diplokaryotic spores were observed primarily in the epithelium of gut and Malpighian tubules. Monokaryotic octospores occurred only in the gut muscle tissues. Fat body tissues were not heavily infected and were atrophied.

\subsection{Ultrastructure}

\subsubsection{Diplokaryotic secondary spore sporulation cycle (S2ss)}

The S2ss meront is round in shape and possesses an electron-lucent cytoplasm. The late-stage meront is elongate and divides by binary fission to form two diplokaryotic sporonts. The S2ss spore is elongate-oval and living spores measured $4.2 \times 2.3 \mu \mathrm{m}$. The exospore is an electron-dense $24.4 \mathrm{~nm}$ thick layer. The endospore is an electron-lucent layer that is, on average, $77.7 \mathrm{~nm}$ thick. Many small bubble-like forms occur in the posterior vacuole. The polar tube is isofilar, with 11-13 coils, most often 12. The polar tube measures $90.8 \pm 7.4 \mathrm{~nm}$ in the diameter and consists of at least three dominant concentric layers.

\subsubsection{Octosporous secondary sporulation cycle (S2oct)}

At the initial stage of octosporous sporulation cycle, a binucleate sporont is surrounded by a thin, electron-dense, sporophorous vesicle (SV) envelope to form a sporophorous vesicle (SV). The S2oct sporont divides to form the uninucleate sporonts surrounded by a thin plasmalemma. The sporont develops within the sporophorous vesicle and divides into lobes. Electron-dense granules were the major type of episporontal inclusions in the sporophorous vesicle during the developmental process. The large granules were composed of three layers. Loosely stacked lamellae appeared in the episporontal space. Electron-lucent tubules and electron-dense tubules were located between the granules and the S2oct sporonts. Polar filament coils number 8-9 in the mature octospores.

\subsection{Deposition of specimens}

Viable spores (Accession No. 2008-C) are maintained in liquid nitrogen storage and in a $4{ }^{\circ} \mathrm{C}$ freezer in the Entomology Department Laboratory of National Taiwan University, Taipei, Taiwan. Living spores are produced in Bombyx mori every 6 months. The SSUrDNA sequence is deposited in NCBI GenBank Accession No. EU338543.

\section{Acknowledgments}

The authors thank the National Science Council, the Council of Agriculture of the Republic of China, National Taiwan University, and the Illinois Natural History Survey at the University of Illinois for financially supporting this research.

\section{Appendix A. Supplementary data}

Supplemental data associated with this article can be found, in the online version, at doi:10.1016/j.jip.2008.11.007.

\section{References}

Canning, E.U., Curry, A., Cheney, S., Lafranchi-Tristem, N.J., Haque, M.A., 1999. Vairimorpha imperfecta n. sp., a microsporidian exhibiting an abortive octosporous sporogony in Plutella xylostella L. (Lepidoptera: Yponomeutidae). Parasitology 119, 273-286.

Canning, E.U., Lom, J., 1986. The Microsporidia of Vertebrates. Academic Press, London. 289 pp.

Darwish, A., Weidner, E., Fuxa, J.R., 1989. Vairimorpha necatrix in adipose cells of Trichoplusia ni. J. Protozool. 36, 308-311.

Huelsenbeck, J.P., Ronquist, F., 2001. MRBAYES: Bayesian inference of phylogenetic trees. Bioinformatics 17, 754-755.

Jouvenaz, D.P., Ellis, E.A., 1986. Vairimorpha invictae n. sp. (Microspora: Microsporida), a parasite of the red imported fire ant, Solenopsis invicta Buren (Hymenoptera: Formicidae). J. Protozool. 33, 457-461.

Ku, C.T., Wang, C.Y., Tsai, Y.C., Tzeng, C.C., Wang, C.H., 2007. Phylogenetic analysis of two putative Nosema isolates from cruciferous lepidopteran pests in Taiwan. J. Invertebr. Pathol. 95, 71-76.

Maddox, J.V., Baker, M.D., Jeffords, M.R., Kuras, M., Linde, A., Solter, L.F., McManus, M.L., Vávra, J., Vossbrinck, C.R., 1999. Nosema portugal n. sp., isolated from gypsy moth (Lymantria dispar L.) collected in Portugal. J. Invertebr. Pathol. 73, 1-14.

McManus, M.L., Solter, L.F., 2003. A Microsporidian pathogens in European gypsy moth populations. In: Proceedings: Ecology, survey, and management of forest insects. USDA Forest Service, Northeast Research Station Gen. Technical Report NE-311, pp. 44-51.

Mitchell, M.J., Cali, A., 1993. Ultrastructural study of the development of Vairimorpha necatrix (Kramer, 1965) (Protozoa, Microsporida) in larvae of the corn earworm, Heliothis zea (Boddie) (Lepidoptera, Noctuidae) with emphasis on sporogony. J. Eukaryot. Microbiol. 40, 701-710.

Moore, C.B., Brooks, W.M., 1992. An ultrastructural study of Vairimorpha necatrix (Microspora, Microsporida) with particular reference to episporontal inclusions during octosporogony. J. Protozool. 39, 392-398.

Moore, C.B., Brooks, W.M., 1994. An ultrastructural study of the episporontal inclusions produced during octosporogony by five species/isolates of Vairimorpha (Microspora: Microsporida). J. Invertebr. Pathol. 63, 197-206.

Moser, B.A., Becnel, J.J., Maruniak, J., Patterson, R.S., 1998. Analysis of the ribosomal DNA sequences of the microsporidia Thelohania and Vairimorpha of fire ants. J. Invertebr. Pathol. 72, 154-159.

Nicholas, K.B., Nicholas Jr., H.B., Deerfield II, D.W., 1997. GeneDoc: analysis and visualization of genetic variation, EMBNEW. NEWS 4, 14. 
Pilley, B.M., 1976. A new genus, Vairimorpha (Protozoa: Microsporida) for Nosema necatrix Kramer 1965: pathogenicity and life cycle in Spodoptera exempta (Lepidoptera: Noctuidae). J. Invertebr. Pathol. 28, 177-183.

Rannala, B., Yang, Z., 1996. Probability distribution of molecular evolutionary trees: a new method of phylogenetic inference. J. Mol. Evol. 43, 304-311.

Rönnebäumer, K., Gro $\beta$, U., Bohne, W., 2008. The nascent parasitophorous vacuole membrane of E. cuniculi is formed by host cell lipids and contains pores allowed nutrient uptake. Eukaryot. Cell 7, 1001-1008.

Solter, L.F., Pilarska, D.K., Vossbrinck, C.F., 2000. Host specificity of microsporidia pathogenic to forest Lepidoptera. Biol. Control 19, 48-56.

Swofford, D.L., 2003. PAUP*, Phylogenetic Analysis Using Parsimony (* and other methods). Sinauer Associates, Sunderland, MA

Thompson, J.D., Gibson, T.J., Plewniak, F., Jeanmougin, F., Higgins, D.G., 1997. The CLUSTAL_X windows interface: flexible strategies for multiple sequence alignment aided by quality analysis tools. Nucleic Acids Res. 25, 4876-4882.

Tsai, S.J., Kou, G.H., Yamane, S., Lo, C.F., Wang, C.H., 2003. The characterization of microsporidian isolates (Nosematidae: Nosema) from five important lepidopteran pests in Taiwan. J. Invertebr. Pathol. 83, 51-59.

Undeen, A.H., Cockburn, A.F., 1989. The extraction of DNA from microsporidia spores. J. Invertebr. Pathol. 54, 132-133.
Vavra, J., Hylis, M., Vossbrinck, C.R., Pilarska, D.K., Linde, A., Weiser, J., Mcmanus, M.L., Hoch, G., Solter, L.F., 2006. Vairimorpha disparis n. comb. (Microsporidia: Burenellidae): A redescription and taxonomic revision of Thelohania disparis Timofejeva 1956, a microsporidian parasite of the gypsy moth Lymantria dispar (L.) (Lepidoptera: Lymantriidae). J. Eukaryot. Microbiol. 53, 292-304.

Vossbrinck, C.R., Baker, M.D., Didier, E.S., Debrunner-Vossbrinck, B.A., Shadduck, J.A., 1993. Ribosomal DNA sequences of Encephalitozoon hellem and Encephalitozoon cuniculi: species identification and phylogenetic construction. J. Eukaryot. Microbiol. 40, 354-362.

Vossbrinck, C.R., Maddox, J.V., Frideman, S., Debrunner-Vossbrinck, B.A., Woese, C.R., 1987. Ribosomal RNA sequence suggests microsporidia are extremely ancient eukaryotes. Nature 326, 411-414.

Wang, C.Y., Solter, L.F., T'sui, W.H., Wang, H.S., 2005. An Endoreticulatus species from Ocinara lida (Lepidoptera: Bombycidae) in Taiwan. J. Invertebr. Pathol. 89, 123135.

Weiser, J., Purrini, K., 1985. Light- and electron-microscopic studies on the microsporidian Vairimorpha ephestiae (Mattes) (Protozoa, Microsporidia) in the meal moth Ephestia kühniella. Arch. Protistenk. 130, 179-189. 